\title{
EFFECT OF CHEMISTRY VARIATIONS IN PLATE AND WELD FILLER METAL ON THE CORROSION PERFORMANCE OF Ni-Cr-MO ALLOYS
}

\author{
David V. Fix \\ Raúl B. Rebak \\ Lawrence Livermore National Laboratory \\ 7000 East Ave, L-631 \\ Livermore, California, 94550 USA
}

\begin{abstract}
The ASTM standard B 575 provides the requirements for the chemical composition of Nickel-Chromium-Molybdenum (Ni-Cr-Mo) alloys such as Alloy 22 (N06022) and Alloy 686 (N06686). The compositions of each element are given in a range. For example, the content of Mo is specified from 12.5 to 14.5 weight percent for Alloy 22 and from 15.0 to 17.0 weight percent for Alloy 686. It was important to determine how the corrosion rate of welded plates of Alloy 22 using Alloy 686 weld filler metal would change if heats of these alloys were prepared using several variations in the composition of the elements even though still in the range specified in B 575. All the material used in this report were especially prepared at Allegheny Ludlum Co. Seven heats of plate were welded with seven heats of wire. Immersion corrosion tests were conducted in a boiling solution of sulfuric acid plus ferric sulfate (ASTM G 28 A) using both as-welded (ASW) coupons and solution heat-treated (SHT) coupons. Results show that the corrosion rate was not affected by the chemistry of the materials in the range of the standards.

Keywords: N06022, N06686, Heat Composition Variability, Corrosion Rate, ASTM G 28A
\end{abstract}

\section{INTRODUCTION}

The composition of engineering alloys such as Alloy 22 (N06022) and 686 (N06686) is given by ASTM standards (B 575). [1] When the alloys are commercially produced their chemical composition may vary slightly from heat to heat while still within the boundaries of the standard specification.

The fabrication history of the original welded plates studied here is given in more detail elsewhere. [2-3] Basically, wrought plates with seven different heats (A through $G$ ) of Alloy 22 (Table 1 in Appendix A) were welded with weld wire from seven different heats ( 1 through 7 ) of Alloy 686 (Table 2 in Appendix A). The Alloy 22 plates were nominally 1-inch thick. The Alloy 686 or ERNiCrMo-14 weld wire was $0.0625-$ inch diameter and met the specifications of ASME SFA-5.14. [4] The welding method was gas tungsten arc welding (GTAW). Welded specimens from these 49 resulting plates were studied both in the as-welded (ASW) condition and in the solution heat-treated (SHT) (annealed) condition. The solution heat treating or annealing was carried in air at $2075^{\circ} \mathrm{F}$ for $1 \mathrm{~h}$ plus rapid cooling (water spraying). [2-3] Immersion corrosion tests were carried out in a boiling solution of sulfuric acid and ferric sulfate (ASTM G $28 \mathrm{~A}$ ). [5]

The objective of this study is to show if small variations in the heat chemistry can affect the corrosion performance of Alloy 22 and Alloy 686.

\section{EXPERIMENTAL}

\section{Preparation of the Corrosion Coupons}

The test material was delivered to Lawrence Livermore National Laboratory in the form of 1 -inch thick welded plates. There were two types of plate strips: (1) As-Welded (ASW) 
and (2) ASW plus solution heat-treated (SHT). The welding and heat treatment were carried out in the primary metal producer plant. [2-3] Table 3 (Appendix A) shows the identification of the coupons prepared from the welded plates. These plates were water-jet cut perpendicularly to the weld in approximately I-inch thick slices. Then, the test coupons were abrasion wheel cut to immersion corrosion testing sizes from the plate slices. Each coupon contained the weld seam on its center and base material at each side of the weld seam. The testing coupons were approximately 0.5 to 1 -inch wide, 0.25 to 0.5 -inch thick and 2 -inch long. These sizes were constrained by the testing apparatus (ASTM G 28) and specimen holder. [5] That is, each coupon had six surfaces. Five of the surfaces were as-cut surfaces (abrasion wheel of water jet) and one surface (top surface) had the mill finish condition. In the case of the ASW + SHT coupons the top surface had also the characteristic black annealing oxide scale. A second batch of coupons were cut from the second "layer" of the plate, that is, the second batch did not contain the original weld surface or the SHT black oxide film on it.

The surface area of the coupons varied generally from 20 to $35 \mathrm{~cm}^{2}$ and the weight in the varied from 30 to $60 \mathrm{~g}$. The coupons were degreased in acetone, rinsed in de-ionized water and let dry in ambient air. Each coupon was labeled, photographed, dimensioned and then weighed three times before the corrosion testing started. At least 200 immersion tests were performed in this testing effort.

\section{Immersion Corrosion Tests (G28 A)}

ASTM G 28 A method measures the susceptibility of nickel alloys to intergranular attack. It is often used to determine preferential intergranular attack near welds or in heat affected zones (HAZ). The guidelines are specified in the Annual Book of ASTM standards. [5] Figure 1 shows the setting for the tests. The ASTM G 28 A method for Alloy 22 consists in immersing coupons of the alloy for $24 \mathrm{~h}$ in a boiling solution of $42 \mathrm{~g} / \mathrm{L} \mathrm{Fe} 2\left(\mathrm{SO}_{4}\right)_{3}$ (ferric sulfate) plus $50 \% \mathrm{H}_{2} \mathrm{SO}_{4}$ (sulfuric acid). This is a highly acidic and oxidizing solution. The difference in the mass of the coupon between before and after the test can be used to calculate the uniform corrosion rate (Equation 1) [5]

$$
C R\left(\frac{m m}{\text { year }}\right)=\frac{8.76 \times 10^{4} \cdot\left(W_{i}-W_{f}\right)(g)}{A\left(\mathrm{~cm}^{2}\right) \cdot t(h) \cdot d\left(\mathrm{~g} \cdot \mathrm{cm}^{-3}\right)}
$$

Where Wi is the initial mass of the coupon, Wf is the mass of the coupon after the $24-\mathrm{h}$ immersion test, $\mathrm{A}$ is the surface area of the coupon, $t$ is the testing time $(24 \mathrm{~h})$ and $d$ is the density of Alloy $22\left(8.69 \mathrm{~g} / \mathrm{cm}^{3}\right)$. [5] Generally, only one coupon was tested for each base-weld combination.

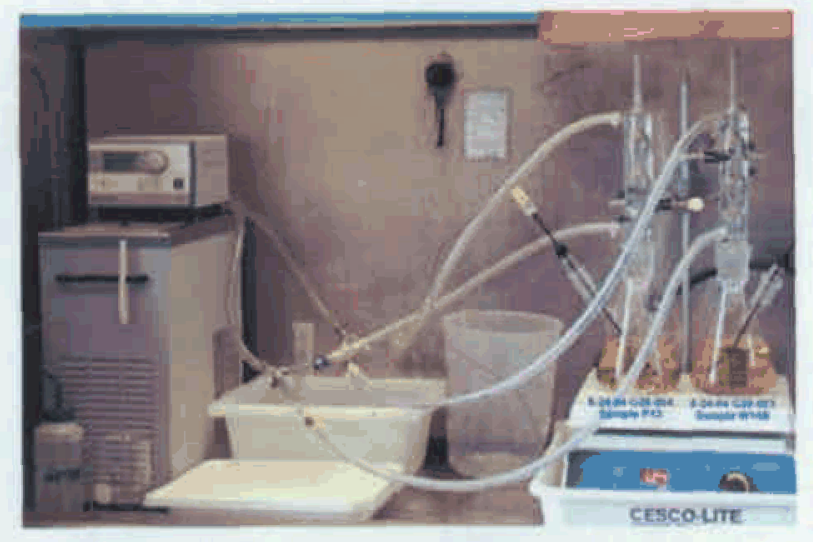

Figure 1. Set-up for immersion corrosion testing

\section{PRELIMINARY RESULTS AND DISCUSSION}

\section{Corrosion Rate from the Top or First Layer Coupons}

Figure 2 shows the general appearance of the top face of ASW $28 R 5$ coupon, before and after the immersion test. Coupon $28 R 5$ corresponded to Base Heat $\mathrm{G}$ welded with Wire Heat 7 (Table 3). Before the test, the coupon had a slight heat tint in the heat affected zone (HAZ) area. After the test, the HAZ appeared darker than the rest of the coupon, suggesting enhanced attack in this area. This can be seen as two darker bands at each side and parallel to the weld seam (Figure 2). The corrosion in the HAZ was mainly intergranular attack (IGA).

Figure 3 shows the general appearance of the top face of the ASW + SHT 73R5 coupon. Before the immersion test, the coupon was covered by a dark (black + dark green) oxide scale produced during the solution annealing and the subsequent water quenching. After the immersion test, most of the oxide scale was washed away and only the weld seam contained remnants of this scale. Many times there were islands of uneven attack in the weld seam within the area covered by the scale. In some weld seams, cavities were found. It is not clear if these cavities were formed during the immersion tests or were weld porosity formed during welding. The black HAZ bands of IGA present in the ASW coupons (Figure 2) were absent in the ASW + SHT coupons (Figure 3 ). The testing coupons were approximately parallelepipeds, that is, they had six faces. Five faces were as-cut faces and were of the same nature for both types of coupons (ASW and ASW + SHT). Whenever comparing surface characteristics after corrosion testing only the face of interest (top face) is discussed. 
28R5-G28-1-F

Aug 17, 2004

Pre Test

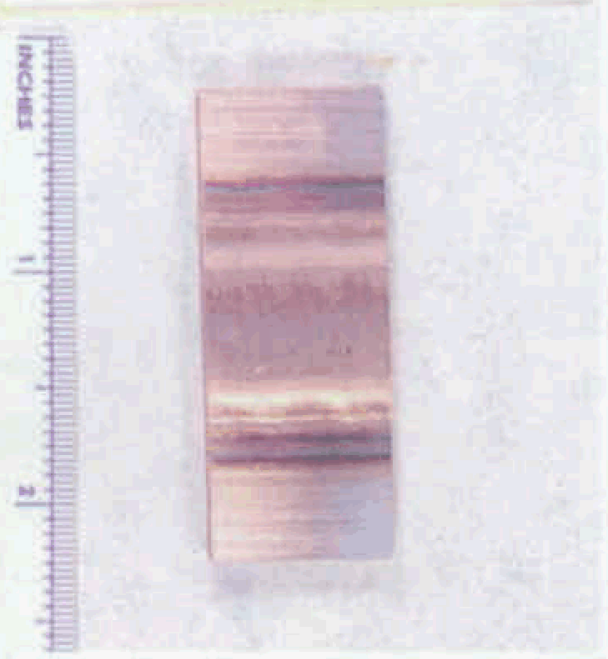

28R5-G28-1-F

Sept. 2, 2004

Post Test

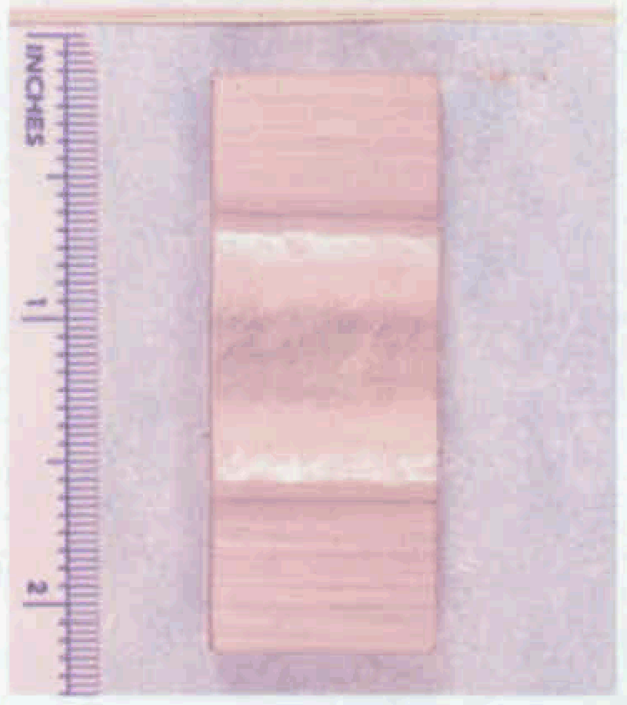

Figure 2. ASW Coupon $28 R 5$ before (top) and after (above) the immersion test

\section{R5-G28-1-F \\ Sept. 9, 2004 \\ Pre Test}

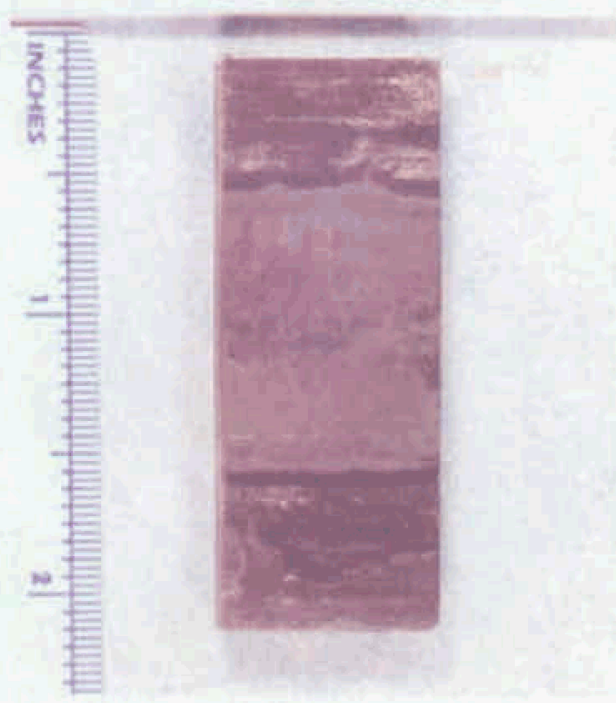

73R5-G28-1-F

Sept. 16, 2004

Post Test

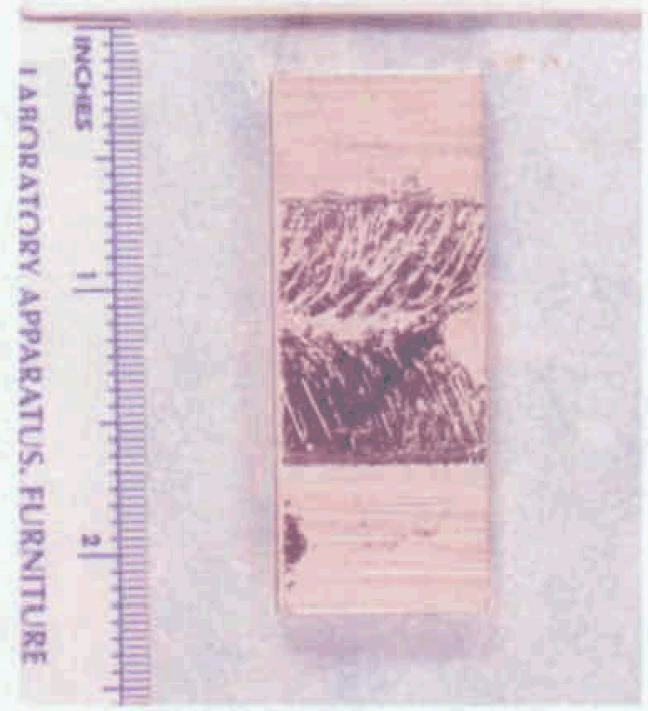

Figure 3. ASW + SHT Coupon $73 R 5$ before (top) and after (above) the immersion test 
Table 4 shows the corrosion rate results from the immersion testing. Figure 4 shows the corrosion rate for all the ASW coupons. Corrosion rate data are single values for each base-weld wire chemistry combination. Nonetheless, it is apparent from Figure 4 that the corrosion rate for most plateweld wire pairs was between 0.8 and $1.2 \mathrm{~mm} /$ year. The corrosion rate of wrought and welded Alloy 22 from the literature and factory data is approximately $1 \mathrm{~mm} /$ year $(40$ mpy). [6-12] Figure 4 shows that there were a few coupons in the middle of the graph that had slightly higher corrosion rates. These coupons were prepared using Weld Wire 4 and base metal with "rich" chemistry (Heats E, F and G) (Table 1). It is likely that the rich chemistries accelerated the precipitation of deleterious ordered phases during welding, which later increased the corrosion rate of the coupons in the HAZ.

Figure 5 shows the corrosion rates for the ASW + SHT coupons. Figure 6 shows comparatively the corrosion rates for the ASW coupons (Figure 4) and the ASW + SHT coupons (Figure 5). In general the corrosion rates of the ASW + SHT coupons were higher than for the ASW coupons (Figure 4), probably because of the dissolution (or detachment) of the black oxide scale from the top surface of the ASW + SHT coupons (Figure 3). That is, the values plotted in Figure 5 are not true corrosion (dissolution) rates (compare later with values in Figure 8). The testing electrolyte was darker after the tests for the ASW + SHT coupons (top layer) than for the ASW coupons (top layer), suggesting more contamination of the electrolyte in the case of the ASW + SHT coupons due to the dissolution of the air oxidized scale. Mori et al. have shown that the corrosion rate of Ni- Cr-Mo alloys in ASTM G 28 solutions is highly dependent on the surface finish of the coupons. [13] Figure 5 shows that the corrosion rate of the ASW + SHT coupons seemed to increase for higher number weld wire heats. The higher number weld wire heats correspond to "richer" chemistries (Table 2), that is, the material that contained the highest amounts of $\mathrm{Cr}$, Mo and $\mathrm{W}$ allowed in B 575. Again, similarly to the data for ASW coupons (Figure 4), the ASW + SHT coupons welded with Wire 4 had higher than expected corrosion rates.

It has been reported previously that the Base Heat $\mathrm{G}$ did not meet the elongation to failure, required for wrought N06022 material, during mechanical testing. [2-3] Weldments produced using Wire 4 produced poor mechanical properties of the material (e.g. reduced tensile strength and low elongation to failure). [2-3] Poor mechanical properties of welded plates were also reported using wires 4 and 7 with plate D. [2-3] For most of the welded plates, a SHT process increased the Charpy toughness of the materials. The toughness of the welded coupons, both ASW and SHT were the lowest for the E, F and $G$ plates welded with wire 4. [2-3] The poor performance of weld Wire 4 was attributed to the high content of residual elements. [2-3] These residual elements include $\mathrm{Fe}, \mathrm{Mn}, \mathrm{V}, \mathrm{Cu}$, $\mathrm{Si}$ and $\mathrm{C}$ (Table 2 in Appendix A). The impurities in weld wire
4 may have also produced higher corrosion rates, probably due to grain boundary segregation effects.

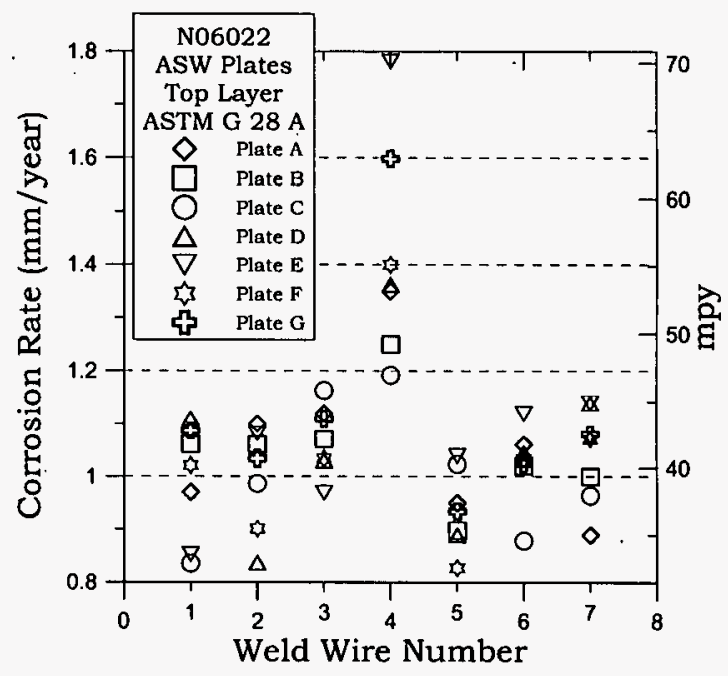

Figure 4. Corrosion Rates for ASW coupons

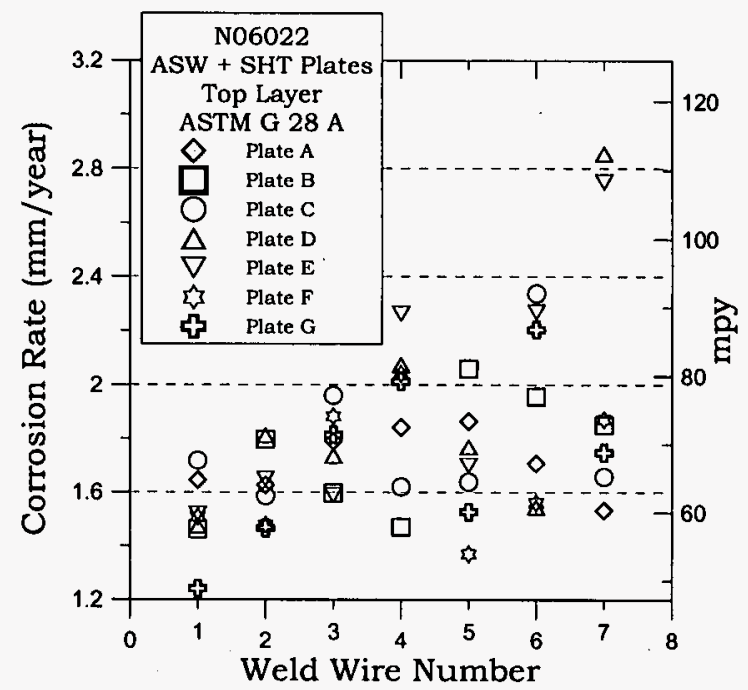

Figure 5. Corrosion Rates for ASW + SHT coupons 


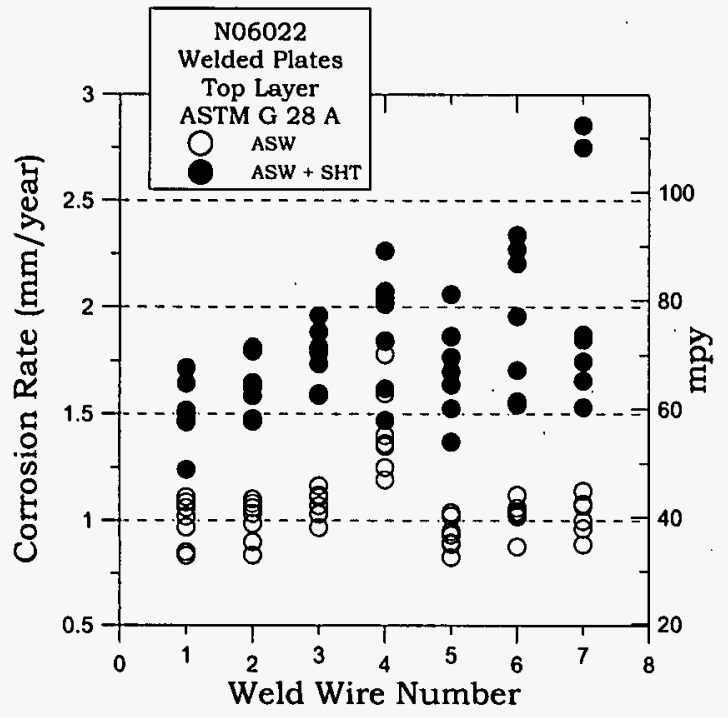

Figure 6. Corrosion Rates for ASW and ASW + SHT coupons

\section{Corrosion Rate from the Second Layer Coupons}

Figures 7 and 8 show the corrosion rates for coupons prepared from the second layer of the ASW and ASW + SHT plates, respectively. Compared to Figures 4 and 5 (top layer), the corrosion rates of the second layer coupons were lower, between 0.7 and $1 \mathrm{~mm} /$ year both for the ASW and ASW + SHT coupons. Figure 9 shows the corrosion rate for ASW and ASW + SHT coupons prepared from the second layer. There is very little difference in the corrosion rate of these two types of materials when the corrosion rate is not affected by the external black scale on the plate. Figure 9 seems to suggest that the corrosion rate of ASW + SHT coupons was slightly lower than that of ASW coupons, showing the beneficial effect of SHT. Figures 10 and 11 compare the corrosion rate for the top and second layer coupons for ASW and ASW + SHT coupons, respectively. In both cases, the corrosion rate of the second layer coupons was lower but this difference was larger for the ASW + SHT coupons since it contained a thicker black oxide scale on the surface. In both cases it can be seen that coupons welded with Weld Wire 4 gave higher corrosion rates. Figures 12 and 13 show the appearance of the ASW and ASW + SHT coupons, respectively from the second layer before and after the corrosion immersion tests. Both coupons show the etching of the weld after the immersion tests. In most cases the weld etching was less conspicuous in the ASW + SHT specimens than in the ASW specimens. Figure 12 shows the black bands of HAZ IGA at both sides of the weld while these bands are absent in Figure 13 suggesting a beneficial effect of SHT. In many of the corrosion tested coupons there were corrosion pits in the fusion line of the weld. Also some coupons showed cracks and apparent corrosion between passes of the weld in the cross section of the coupons. This attack does not seem to be important enough to be manifested as higher corrosion rates (Figures 4 though 11). That is, the corrosion rate was always the same regardless if the coupons had inter-pass attack or not.

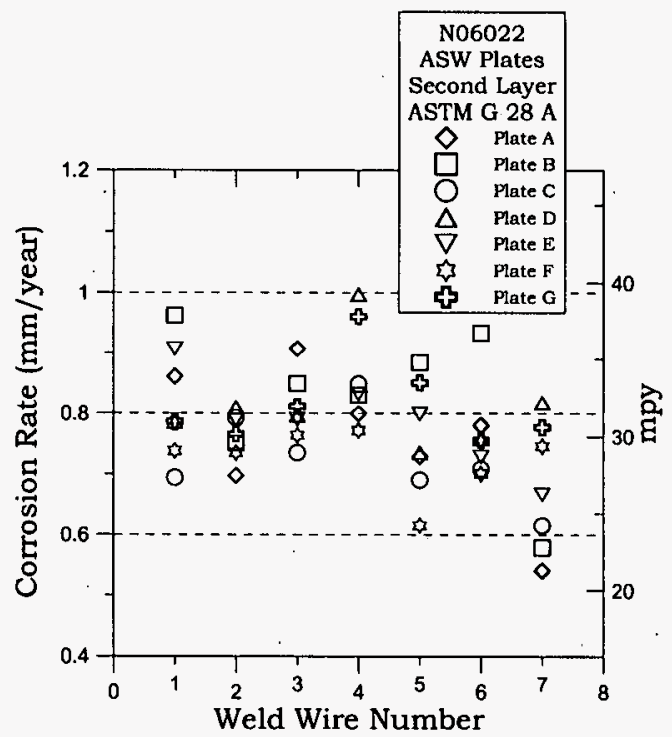

Figure 7. Corrosion Rates for Second-Layer ASW coupons

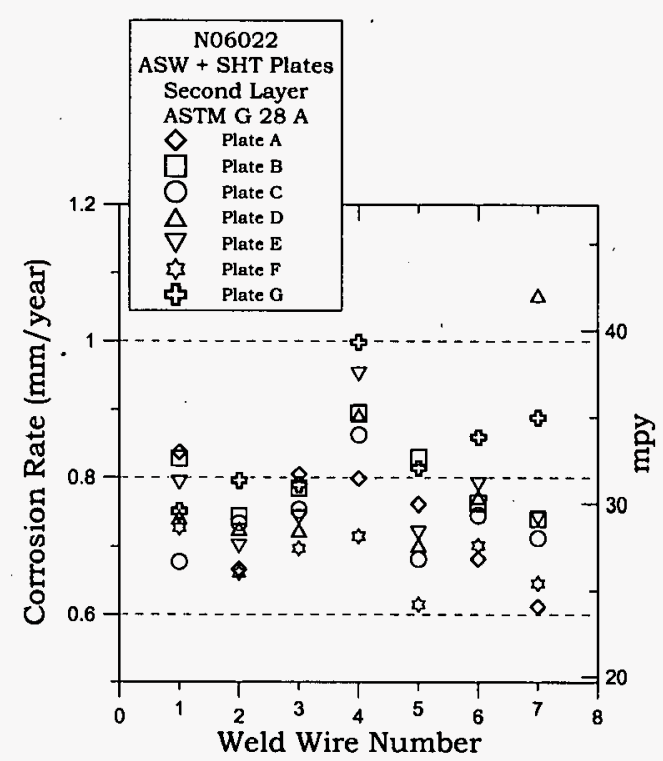

Figure 8. Corrosion Rates for Second-Layer ASW + SHT coupons 


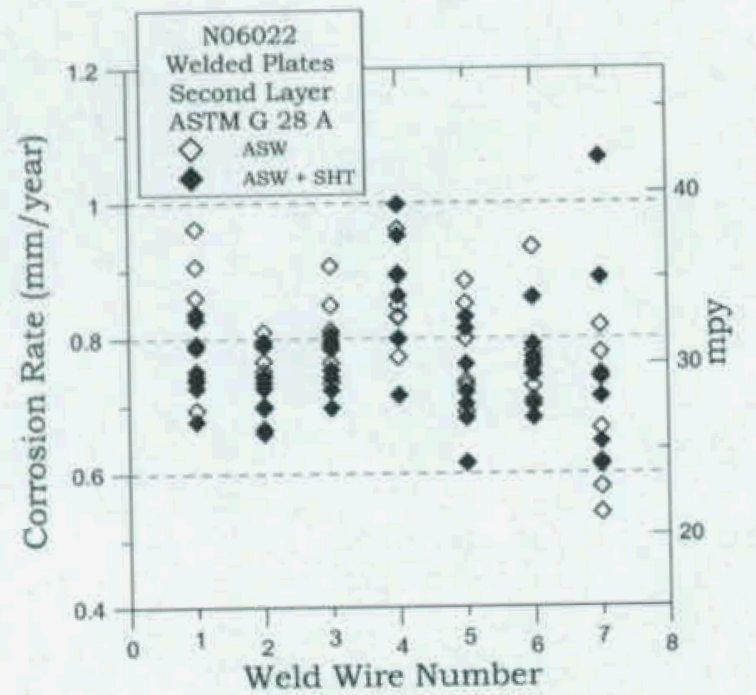

Figure 9. Corrosion Rates for Second-Layer ASW and ASW + SHT coupons

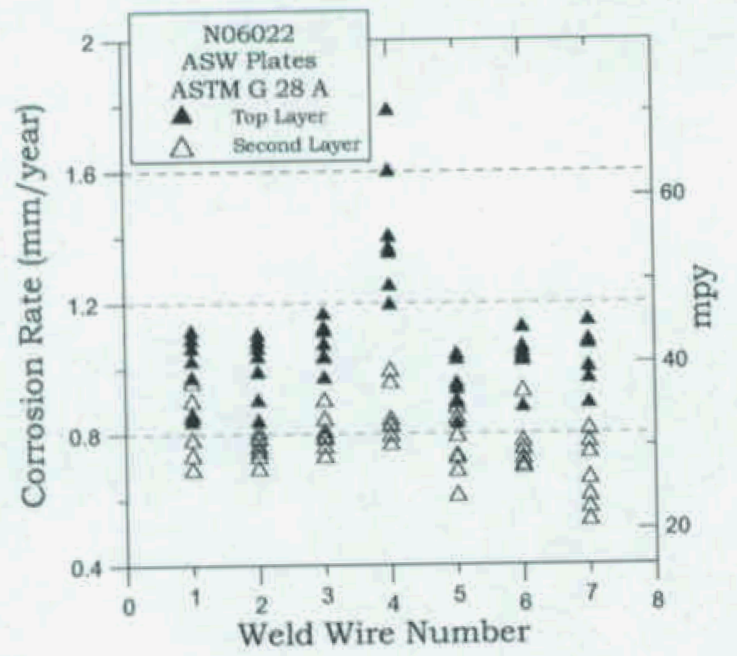

Figure 10. Corrosion Rates for Top and Second-Layer ASW coupons

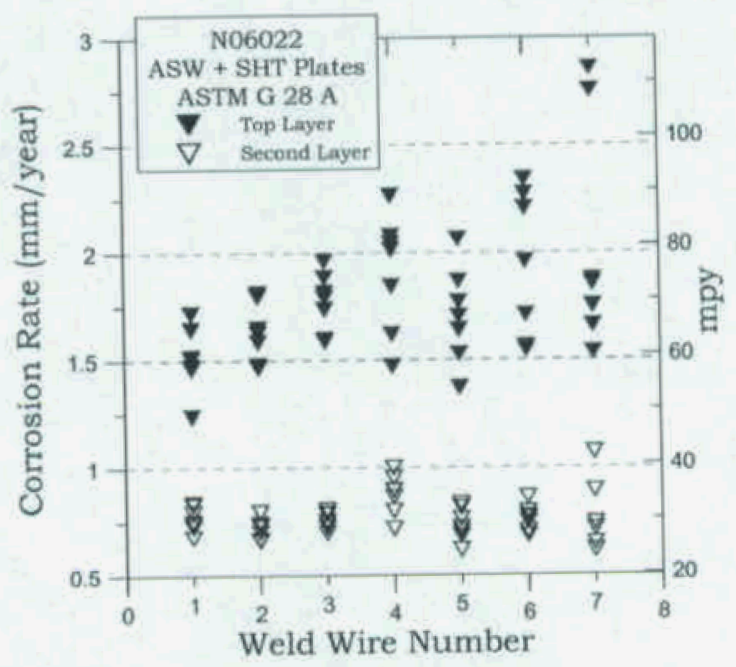

Figure 11. Corrosion Rates for Top and Second-Layer $A S W+S H T$ coupons

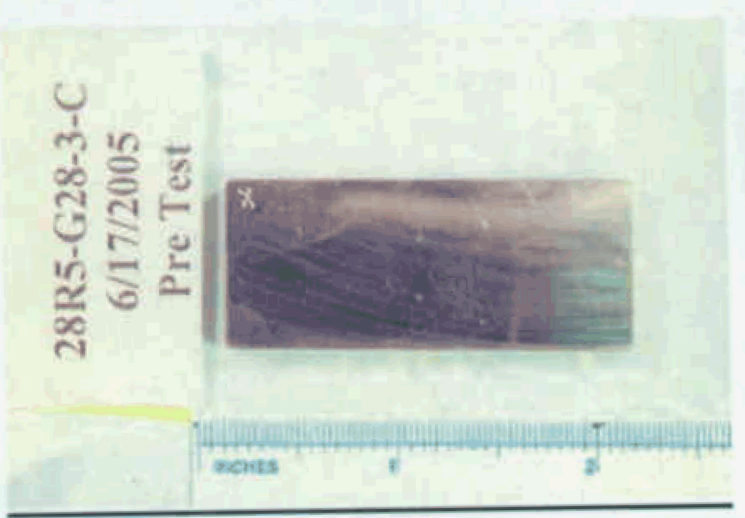

Figure 12a. Coupon 28R5 from the Second Layer ASW plate (Before the Immersion Test)

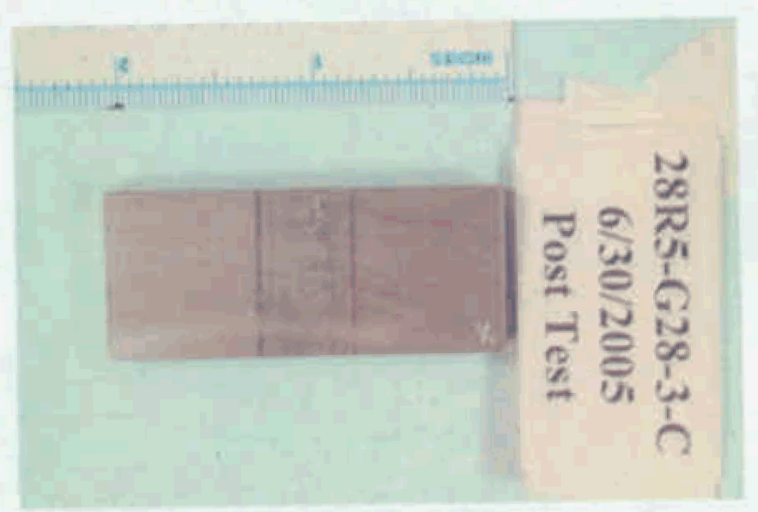

Figure 12b. Coupon $28 \mathrm{R} 5$ from the Second Layer ASW plate (After the Immersion Test) 


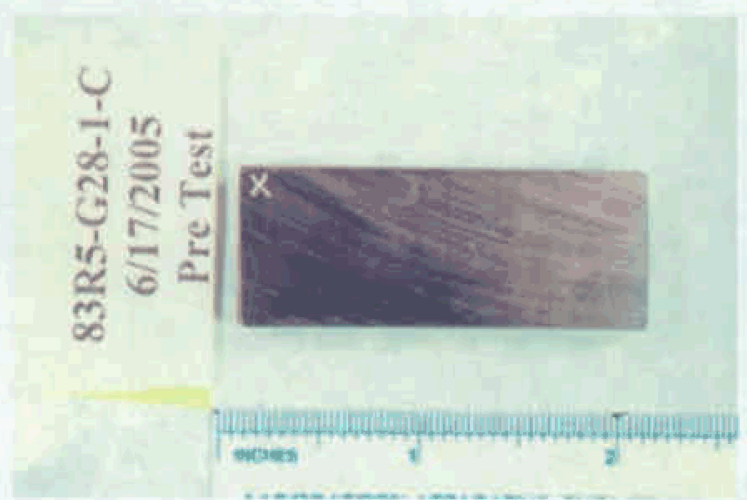

Figure 13a. Coupon $83 R 5$ from the Second Layer ASW + SHT plate (Before the Immersion Test)

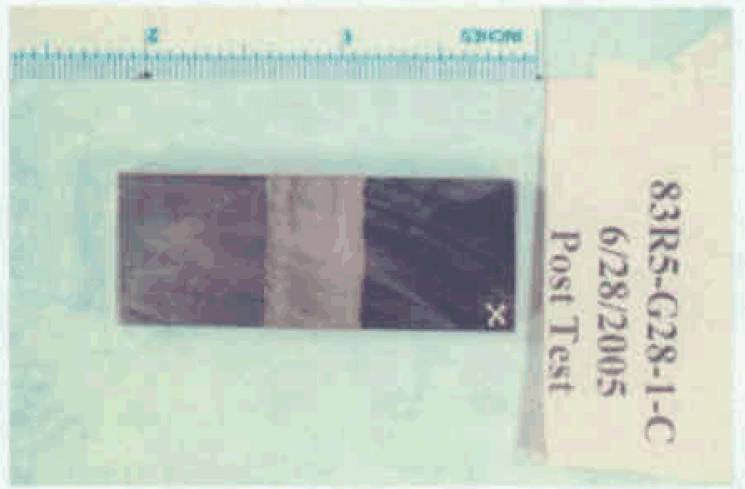

Figure 13b. Coupon $83 R 5$ from the Second Layer ASW + SHT plate (After the Immersion Test)

\section{Final Remarks}

Results from the current testing show that variations in the chemistry of both Alloy 22 and Alloy 686 within the range provided by the guiding standards (e.g. ASTM B 575) do not affect the corrosion performance of these alloys. This is not surprising since when a primary metal producer develops and patents a new alloy, many different chemical compositions of the developed alloy are tested both for mechanical properties and for corrosion resistance in several types of electrolytes, generally from acidic reducing to acidic oxidizing. Later, the ranges of the chemical composition that give the desirable mechanical and corrosion properties are written into the standards which are presented to and accepted by committees within societies such as ASTM of ASME. That is, the fact that the current test program failed to detect a change in the corrosion resistance of the alloys when their composition is varied within the margins of the approved standard could have been predicted based on the industrial experience. Even though some rich chemical compositions (when all important alloying elements such as $\mathrm{Cr}$, Mo and $\mathrm{W}$ are at their maximum allowed concentration) gave slightly different behavior, it is unlikely that a commercial heat will have the maximum content of all the important elements, purely for economical reasons.

\section{CONCLUSIONS}

- Corrosion rate of as-welded coupons of Alloy 22 plates with Alloy 686 wires in ASTM G 28 A solution were comparable to published data and in the order of $1 \mathrm{~mm} /$ year (40 mpy)

- The corrosion rate of welded plus solution heat treated (ASW + SHT) coupons were higher than for ASW coupons, because the former contained a black oxide scale in the surface that disintegrated during corrosion testing

- When coupons were prepared from the second layer of the plates (without the black oxide scale on the surface) the corrosion rates of the ASW and the ASW + SHT coupons were similar.

- In the range of the accepted chemistry of commercial materials the corrosion rate of one heat usually is indistinguishable from the corrosion rate of another heat.

\section{ACKNOWLEDGMENTS}

This work was partially performed under the auspices of the U.S. Department of Energy by the University of California Lawrence Livermore National Laboratory under contract W-7405-Eng-48. The work was supported by the Yucca Mountain Project, which is part of the DOE Office of Civilian Radioactive Waste Management (OCRWM). 


\section{DISCLAIMER}

This document was prepared as an account of work sponsored by an agency of the United States Government. Neither the United States Government nor the University of California nor any of their employees, makes any warranty, express or implied, or assumes any legal liability or responsibility for the accuracy, completeness, or usefulness of any information, apparatus, product, or process disclosed, or represents that its use would not infringe privately owned rights. Reference herein to any specific commercial product, process, or service by trade name, trademark, manufacturer, or otherwise, does not necessarily constitute or imply its endorsement, recommendation, or favoring by the United States Government or the University of California. The views and opinions of authors expressed herein do not necessarily state or reflect those of the United States Government or the University of California, and shall not be used for advertising or product endorsement purposes.

\section{REFERENCES}

1. ASTM International, Annual Book of ASTM Standards, Volume 02.04 "Non-Ferrous Metals" Standard B-575 (West Conshohocken, PA: ASTM International, 2004).

2. Allegheny Technologies, Report on "Nickel-Based Alloy Weld Filler Material and Base Metal Composition Test Program', Report 004223-REV 000, March 2004 (Allegheny Technologies, 2004: Albany, OR).

3. Waste Package and Drip Shield Corrosion, Technical Basis Document $\mathrm{N}^{\circ}$ 6, Appendix T "Microstructural and Compositional Variations of Alloy 22," June 2004 (BSC, 2004: Las Vegas; NV)
4. ASME (American Society of Mechanical Engineers), 2001 ASME Boiler and Pressure Vessel Code (ASME, 2001: New York, NY).

5. ASTM International, Annual Book of ASTM Standards, Volume 03.02 "Wear and Erosion; Metal Corrosion" p. 91 (West Conshohocken, PA: ASTM International, 2004).

6. Haynes International Inc., "Hastelloy C-22 Alloy," Product Brochure H-2019E (1997).

7. R. B. Rebak and N. E. Koon, Corrosion/1998, Paper 153 (NACE International, 1998: Houston, TX).

8. R. B. Rebak, N. E. Koon, J. R. Dillman, P. Crook and T. S. E. Summers, Corrosion/2000, Paper 00181 (NACE International, 2000: Houston, TX).

9. R. B. Rebak, T. S. E. Summers, T. Lian, R. M. Carranza, J. R. Dillman, T. Corbin and P. Crook "Effect of Thermal Aging on the Corrosion Behavior of Wrought and Welded Alloy 22," Corrosion/2002, Paper 02542 (NACE International, 2002: Houston, TX).

10. R. B. Rebak and P. Crook, PVP-Vol. 449, p. 111 (ASME, 2002: New York, NY).

11. R. B. Rebak, ASM Metals Handbook, Vol. 13A, p. 279 (ASM International, 2003, Metals Park, OH).

12. R. B. Rebak and P. Crook, PVP-Vol. 483, p. 131 (ASME, 2004: New York, NY).

13. G. Mori, S. Sutthiruangwong, M. Czerny and T. Partlic, Corrosion, 60, 1082 (2004). 


\section{APPENDIX A}

Table 1. Approximate Average Chemical Composition of the N06022 Plates (Heats A-G)

\begin{tabular}{|c|c|c|c|c|c|c|c|}
\hline Element $\downarrow$ Heat $\rightarrow$ & $\mathbf{A}$ & $\mathbf{B}$ & $\mathbf{C}$ & $\mathbf{D}$ & $\mathbf{E}$ & $\mathbf{F}$ & $\mathbf{G}$ \\
\hline $\mathrm{Ni}$ & 61.6 & 59.6 & 58.5 & 56.00 & 56.3 & 58.1 & 53.9 \\
\hline $\mathrm{Cr}$ & 20.3 & 20.8 & 21.1 & 21.3 & 21.6 & 21.8 & 22.5 \\
\hline Mo & 12.7 & 13.3 & 13.1 & 13.6 & 13.7 & 13.8 & 14.2 \\
\hline $\mathrm{W}$ & 2.7 & 3.0 & 3.0 & 3.0 & 3.0 & 3.0 & 3.4 \\
\hline $\mathrm{Fe}$ & 2.5 & 3.0 & 4.0 & 3.0 & 5.0 & 3.0 & 5.8 \\
\hline Co & 0.15 & ND & ND & 2.23 & ND & 0.03 & ND \\
\hline $\mathrm{Mn}$ & 0.02 & 0.02 & 0.01 & 0.4 & 0.04 & 0.02 & 0.03 \\
\hline $\mathrm{Al}$ & 0.18 & 0.15 & 0.17 & 0.15 & 0.15 & 0.19 & 0.20 \\
\hline $\mathrm{V}$ & ND & ND & ND & 0.25 & 0.01 & 0.01 & 0.01 \\
\hline $\mathrm{Cu}$ & 0.01 & 0.01 & ND & 0.02 & ND & 0.01 & ND \\
\hline $\mathrm{Si}$ & 0.03 & 0.03 & 0.03 & 0.07 & 0.04 & 0.05 & 0.05 \\
\hline C & 0.004 & 0.004 & 0.006 & 0.005 & 0.01 & 0.014 & 0.007 \\
\hline $\mathrm{S}$ & 0.0003 & ND & ND & ND & ND & ND & ND \\
\hline$P$ & 0.003 & 0.004 & 0.004 & ND & 0.006 & 0.005 & 0.006 \\
\hline \multirow{2}{*}{\multicolumn{8}{|c|}{ ND = Not Detected (Below the Detection Limit) }} \\
\hline & & & & & & & \\
\hline
\end{tabular}

Table 2. Approximate Average Chemical Composition of the N06686 Weld Wires (Heats 1-7)

\begin{tabular}{|c|c|c|c|c|c|c|c|}
\hline Element $\downarrow$ Heat $\rightarrow$ & 1 & 2 & 3 & 4 & 5 & 6 & 7 \\
\hline$\overline{\mathrm{Ni}}$ & 61.9 & 60.4 & 58.8 & 53.6 & 57.8 & 56.8 & 55.6 \\
\hline $\mathrm{Cr}$ & 19.3 & 19.8 & 20.5 & 20.6 & 21.6 & 22.3 & 22.9 \\
\hline Mo & 15.1 & 15.8 & 16.3 & 16.3 & 16.3 & 16.3 & 16.8 \\
\hline$\overline{\mathrm{W}}$ & 3.2 & 3.5 & 3.7 & 3.8 & 3.8 & 4.0 & 4.3 \\
\hline $\mathrm{Fe}$ & ND & 0.42 & 0.39 & 4.03 & 0.28 & 0.35 & 0.14 \\
\hline Co & ND & ND & ND & 0.02 & ND & ND & ND \\
\hline $\mathrm{Mn}$ & ND & ND & ND & 0.89 & ND & ND & ND \\
\hline $\mathrm{Al}$ & 0.15 & 0.16 & 0.17 & 0.06 & 0.18 & 0.16 & 0.16 \\
\hline $\mathrm{V}$ & ND & ND & ND & 0.11 & ND & ND & ND \\
\hline$\overline{\mathrm{Cu}}$ & $\overline{\mathrm{ND}}$ & 0.01 & 0.01 & 0.43 & 0.01 & 0.01 & 0.01 \\
\hline $\mathrm{Si}$ & 0.02 & 0.02 & 0.03 & 0.08 & 0.02 & 0.03 & 0.03 \\
\hline $\bar{C}$ & 0.004 & 0.005 & 0.002 & 0.005 & 0.001 & 0.001 & 0.002 \\
\hline $\mathrm{S}$ & ND & ND & ND & ND & ND & ND & ND \\
\hline $\bar{P}$ & ND & 0.006 & 0.007 & ND & 0.008 & 0.008 & 0.01 \\
\hline \multirow{2}{*}{\multicolumn{8}{|c|}{ ND = Not Detected (Below the Detection Limit) }} \\
\hline & & & & & & & \\
\hline
\end{tabular}


Table 3. Welded Plates Designation Based on the Chemistry of Base Plate and Weld Wire

\begin{tabular}{|c|c|c|c|c|c|}
\hline $\begin{array}{l}\text { Chemistry of } \\
\text { Base and Weld }\end{array}$ & ASW Plate ID & $\begin{array}{c}\text { ASW + SHT } \\
\text { Plate ID }\end{array}$ & $\begin{array}{c}\text { Chemistry of } \\
\text { Base and Weld }\end{array}$ & ASW Plate ID & $\begin{array}{l}\text { ASW + SHT } \\
\text { Plate ID }\end{array}$ \\
\hline $\mathrm{A} 1$ & 4R5 & 5R5 & E1 & $8 \mathrm{R} 5$ & 9R5 \\
\hline $\mathrm{A} 2$ & 14R5 & $15 \mathrm{R} 5$ & E2 & $18 \mathrm{R} 5$ & 19R5 \\
\hline $\mathrm{A} 3$ & 64R5 & 65R5 & E3 & 70R5 & 71R5 \\
\hline A4 & $84 \mathrm{R} 5$ & $85 \mathrm{R} 5$ & E4 & 190R5 & 91R5 \\
\hline A5 & 42R5 & 43R5 & E5 & 46R5 & 47R5 \\
\hline A6 & 50R5 & 51R5 & E6 & 58R5 & 59R5 \\
\hline A7 & 30R5 & 31R5 & E7 & $34 \mathrm{R} 5$ & 135R5 \\
\hline B1 & 6R5 & $7 \mathrm{R5}$ & F1 & $2 \mathrm{R} 5$ & 3R5 \\
\hline B2 & $17 \mathrm{R} 5$ & $16 \mathrm{R} 5$ & $\mathrm{~F} 2$ & $12 \mathrm{R} 5$ & 13R5 \\
\hline B3 & 66R5 & 67R5 & F3 & $72 R 5$ & 73R5 \\
\hline B4 & $82 \mathrm{R} 5$ & $83 R 5$ & $\mathrm{~F} 4$ & $88 R 5$ & $89 \mathrm{R} 5$ \\
\hline B5 & 44R5 & $45 \mathrm{R} 5$ & F5 & $38 \mathrm{R} 5$ & $39 \mathrm{R} 5$ \\
\hline B6 & 56R5 & 57R5 & F6 & $54 \mathrm{R} 5$ & 55R5 \\
\hline B7 & $32 \mathrm{R} 5$ & $33 \mathrm{R5}$ & F7 & 26R5 & 127R5 \\
\hline $\mathrm{Cl}$ & 10R5 & 11R5 & G1 & $24 \mathrm{R} 5$ & $25 \mathrm{R} 5$ \\
\hline $\mathrm{C} 2$ & 120R5 & 21R5 & G2 & 122R5 & 23R5 \\
\hline $\mathrm{C} 3$ & 168R5 & 69R5 & G3 & 162R5 & 63R5 \\
\hline $\mathrm{C} 4$ & 92R5 & 93R5 & G4 & 98R5 & 99R5 \\
\hline $\mathrm{C} 5$ & 148R5 & 49R5 & G5 & 40R5 & 41R5 \\
\hline C6 & $60 \mathrm{R} 5$ & $61 R 5$ & G6 & $52 \mathrm{R} 5$ & 53R5 \\
\hline $\mathrm{C} 7$ & $36 \mathrm{R} 5$ & 37R5 & G7 & $28 \mathrm{R} 5$ & $29 \mathrm{R} 5$ \\
\hline D1 & $94 \mathrm{R} 5$ & $95 \mathrm{R} 5$ & & & \\
\hline $\mathrm{D} 2$ & 96R5 & 97R5 & & & \\
\hline D3 & $80 \mathrm{R} 5$ & $81 R 5$ & & & \\
\hline $\mathrm{D} 4$ & $86 \mathrm{R} 5$ & 87R5 & & & \\
\hline D5 & $78 \mathrm{R} 5$ & 79R5 & & & \\
\hline D6 & 74R5 & $75 \mathrm{R} 5$ & & & \\
\hline D7 & 176R5 & 177R5 & & & \\
\hline & & & & & \\
\hline
\end{tabular}


Table 4. Corrosion Rate in ASTM G 28A of Coupons Prepared from Welded Plates

\begin{tabular}{|c|c|c|c|c|c|c|c|}
\hline $\begin{array}{l}\text { ASW Plate } \\
\text { ID }\end{array}$ & $\begin{array}{c}\text { Corrosion } \\
\text { Rate } \\
\text { (mm/year) }\end{array}$ & $\begin{array}{l}\text { ASW + } \\
\text { SHT Plate } \\
\text { ID }\end{array}$ & $\begin{array}{c}\text { Corrosion } \\
\text { Rate } \\
\text { (mm/year) }\end{array}$ & $\begin{array}{l}\text { ASW Plate } \\
\text { ID }\end{array}$ & $\begin{array}{c}\text { Corrosion } \\
\text { Rate } \\
\text { (mm/year) }\end{array}$ & $\begin{array}{l}\text { ASW + } \\
\text { SHT Plate } \\
\text { ID }\end{array}$ & $\begin{array}{c}\text { Corrosion } \\
\text { Rate } \\
\text { (mm/year) }\end{array}$ \\
\hline 4R5 & 0.97 & 5R5 & 1.64 & 8R5 & 0.85 & $9 \mathrm{R} 5$ & 1.52 \\
\hline 14R5 & 1.10 & $15 \mathrm{R} 5$ & 1.63 & $18 \mathrm{R} 5$ & 1.08 & 19R5 & 1.65 \\
\hline 64R5 & 1.12 & $65 \mathrm{R} 5$ & 1.79 & $70 \mathrm{R} 5$ & 0.97 & 71R5 & 1.59 \\
\hline $84 R 5$ & 1.35 & $85 \mathrm{R} 5$ & 1.84 & 190R5 & 1.78 & $91 \mathrm{R} 5$ & 2.26 \\
\hline $42 \mathrm{R} 5$ & 0.95 & 43R5 & 1.86 & 46R5 & 1.04 & $47 \mathrm{R} 5$ & 1.70 \\
\hline 50R5 & 1.06 & 51R5 & 1.71 & 58R5 & 1.12 & 59R5 & 2.27 \\
\hline 30R5 & 0.89 & $31 \mathrm{R5}$ & 1.53 & \begin{tabular}{|l}
$34 \mathrm{R} 5$ \\
\end{tabular} & 1.14 & $135 \mathrm{R} 5$ & 2.75 \\
\hline 6R5 & 1.06 & $7 \mathrm{R} 5$ & 1.46 & \begin{tabular}{|l|}
$2 \mathrm{R} 5$ \\
\end{tabular} & 102 & $3 \mathrm{R} 5$ & 151 \\
\hline 17R5 & 1.06 & 16R5 & 1.80 & $12 \mathrm{R} 5$ & 0.90 & $13 \mathrm{R} 5$ & 1.48 \\
\hline 66R5 & 1.07 & $67 \mathrm{R} 5$ & 1.60 & 72R5 & 1.03 & $73 \mathrm{R} 5$ & 1.88 \\
\hline $82 R 5$ & 1.25 & $83 \mathrm{R} 5$ & 1.47 & $88 \mathrm{R} 5$ & 1.40 & $89 \mathrm{R} 5$ & 2.04 \\
\hline $44 \mathrm{R5}$ & 0.90 & $45 \mathrm{R} 5$ & 2.06 & \begin{tabular}{|l|} 
38R5 \\
\end{tabular} & 0.83 & $39 \mathrm{R} 5$ & 1.37 \\
\hline 56R5 & 1.02 & 57R5 & 1.96 & 54R5 & 1.03 & $55 \mathrm{R} 5$ & 1.56 \\
\hline $32 \mathrm{R} 5$ & 1.00 & 33R5 & 1.85 & $26 \mathrm{R} 5$ & 1.07 & 127R5 & 1.87 \\
\hline 10R5 & & & & & & & \\
\hline 120R5 & $\begin{array}{l}0.84 \\
0.99\end{array}$ & $\frac{11 R 5}{2185}$ & $\frac{1.12}{1.59}$ & \begin{tabular}{|l|} 
24R5 \\
$122 R 5$
\end{tabular} & 1.09 & $25 \mathrm{R} 5$ & $\frac{1.24}{1.47}$ \\
\hline 168R5 & 1.16 & $69 \mathrm{R} 5$ & 1.96 & \begin{tabular}{|l|}
$162 \mathrm{R} 5$ \\
\end{tabular} & 1.05 & $63 \mathrm{R} 5$ & $\frac{1.41}{1.81}$ \\
\hline $92 \mathrm{R5}$ & 1.19 & 93R5 & 1.62 & 98R5 & 1.60 & 99R5 & 2.01 \\
\hline 148R5 & 1.02 & 49R5 & 1.64 & 40R5 & 0.93 & $41 R 5$ & 1.53 \\
\hline 60R5 & 0.88 & $61 \mathrm{R5}$ & 2.34 & $52 \mathrm{R5}$ & 1.02 & 53R5 & 2.20 \\
\hline $36 \mathrm{R5}$ & 0.96 & $37 \mathrm{R} 5$ & 1.66 & 28R5 & 1.08 & $29 \mathrm{R} 5$ & 1.75 \\
\hline 94R5 & 1.11 & $95 \mathrm{R} 5$ & 1.47 & & & & \\
\hline 96R5 & 0.84 & 97R5 & 181 & & & & \\
\hline $80 \mathrm{R5}$ & 1.03 & $81 \mathrm{R} 5$ & 1.74 & & & & \\
\hline 86R5 & 1.36 & $87 \mathrm{R} 5$ & 2.07 & & & & \\
\hline $78 \mathrm{R5}$ & 0.89 & 79R5 & 1.77 & & & & \\
\hline 74R5 & 1.04 & $75 \mathrm{R} 5$ & 1.54 & & & & \\
\hline 176R5 & 1.14 & 177R5 & 2.86 & & & & \\
\hline & & & & & & & \\
\hline \multicolumn{8}{|c|}{ The top layer corresponds to the coupons that had the original surface of the welded plates } \\
\hline
\end{tabular}


Table 5. Corrosion Rate in ASTM G 28A of Coupons Prepared from the Second Layer of the Welded Plates

\begin{tabular}{|c|c|c|c|c|c|c|c|}
\hline $\begin{array}{l}\text { ASW Plate } \\
\quad \text { ID }\end{array}$ & $\begin{array}{c}\text { Corrosion } \\
\text { Rate } \\
\text { (mm/year) }\end{array}$ & $\begin{array}{c}\text { ASW + } \\
\text { SHT Plate } \\
\text { ID }\end{array}$ & $\begin{array}{c}\text { Corrosion } \\
\text { Rate } \\
\text { (mm/year) }\end{array}$ & $\begin{array}{l}\text { ASW Plate } \\
\text { ID }\end{array}$ & $\begin{array}{c}\text { Corrosion } \\
\text { Rate } \\
\text { (mm/year) }\end{array}$ & $\begin{array}{c}\text { ASW + } \\
\text { SHT Plate } \\
\text { ID }\end{array}$ & $\begin{array}{c}\text { Corrosion } \\
\text { Rate } \\
\text { (mm/year) }\end{array}$ \\
\hline 4R5 & 0.86 & 5R5 & 0.84 & $8 \mathrm{R} 5$ & 0.91 & 9R5 & 0.79 \\
\hline 14R5 & 0.70 & 15R5 & 0.67 & 18R5 & 0.79 & 19R5 & 0.70 \\
\hline 64R5 & 0.91 & $65 \mathrm{R} 5$ & 0.80 & $70 \mathrm{R} 5$ & 0.79 & $71 \mathrm{R5}$ & 0.74 \\
\hline 84R5 & 0.80 & 85R5 & 0.80 & 190R5 & 0.83 & 91R5 & 0.95 \\
\hline 42R5 & 0.73 & 43R5 & 0.76 & 46R5 & 0.80 & 47R5 & 0.72 \\
\hline 50R5 & 0.78 & $51 \mathrm{R5}$ & 0.68 & 58R5 & 0.73 & 59R5 & 0.79 \\
\hline 30R5 & 0.54 & 31R5 & 0.61 & 34R5 & 0.67 & 135R5 & 0.74 \\
\hline 6R5 & 0.96 & 7R5 & 0.83 & $2 \mathrm{R} 5$ & 0.74 & 3R5 & 0.73 \\
\hline 17R5 & 0.75 & 16R5 & 0.74 & 12R5 & 0.73 & 13R5 & 0.66 \\
\hline $66 \mathrm{R} 5$ & 0.85 & 67R5 & 0.78 & 72R5 & 0.76 & 73R5 & 0.70 \\
\hline 82R5 & 0.83 & 83R5 & 0.90 & 88R5 & 0.77 & 89R5 & 0.72 \\
\hline 44R5 & 0.88 & 45R5 & 0.83 & 38R5 & 0.62 & 39R5 & 0.61 \\
\hline 56R5 & 0.93 & 57R5 & 0.76 & 54R5 & 0.70 & 55R5 & 0.70 \\
\hline 32R5 & 0.58 & 33R5 & 0.74 & 26R5 & 0.75 & 127R5 & 0.65 \\
\hline 10R5 & 0.69 & 11R5 & 0.68 & 24R5 & 0.79 & 25R5 & 0.75 \\
\hline 120R5 & 0.79 & 21R5 & 0.73 & 122R5 & 0.77 & 23R5 & 0.80 \\
\hline 168R5 & 0.74 & 69R5 & 0.75 & 162R5 & 0.81 & 63R5 & 0.79 \\
\hline 92R5 & 0.85 & 93R5 & 0.86 & 98R5 & 0.96 & 99R5 & 1.00 \\
\hline 148R5 & 0.69 & 49R5 & 0.68 & 40R5 & 0.85 & 41R5 & 0.81 \\
\hline 60R5 & 0.71 & 61R5 & 0.75 & 52R5 & 0.76 & 53R5 & 0.86 \\
\hline 36R5 & 0.62 & 37R5 & 0.71 & 28R5 & 0.78 & 29R5 & 0.89 \\
\hline 94R5 & 0.79 & 95R5 & 0.74 & & & & \\
\hline 96R5 & 0.81 & 97R5 & 0.73 & & & & \\
\hline $80 \mathrm{R} 5$ & 0.80 & $81 \mathrm{R5}$ & 0.72 & & & & \\
\hline 86R5 & 1.00 & 87R5 & 0.89 & & & & \\
\hline 78R5 & 0.74 & 79R5 & 0.70 & & & & \\
\hline $74 \mathrm{R5}$ & 0.76 & 75R5 & 0.77 & & & & \\
\hline 176R5 & 0.82 & 177R5 & 1.07 & & & & \\
\hline \multicolumn{8}{|c|}{$\begin{array}{l}\text { The Second Layer corresponds to the section of the plate just below the coupons reported in Table } 4 \text {. These } \\
\text { coupons were between } 1 / 4 \text { to } 1 / 2 \text { of the plate thickness }\end{array}$} \\
\hline & & & & & & & \\
\hline
\end{tabular}

